\title{
Growth hormone deficiency as a complication of haemophilia - a case report and literature data
}

Somatotropinowa niedoczynność przysadki jako powikłanie hemofilii - opis przypadku i dane z literatury

\author{
${ }^{1}$ Anna M. Kucharska, ${ }^{2}$ Paweł Łaguna, ${ }^{2}$ Anna Adamowicz-Salach, 'Ewelina Witkowska-Sędek, \\ ${ }^{2}$ Anna Klukowska \\ ${ }^{1}$ Department of Pediatrics and Endocrinology, Warsaw Medical University, Warsaw, Poland \\ ${ }^{2}$ Department of Pediatrics, Oncology and Hematology, Warsaw Medical University, Warsaw, Poland
}

\begin{abstract}
Severe haemophilia carries an increased risk of life-threatening intracranial haemorrhages. Studies in adult survivors show a relatively high percentage of anterior pituitary hypofunction reported as the most frequent complication. We report the case of isolated growth hormone deficiency in a boy with severe haemophilia A. He experienced several intracranial haemorrhages in early childhood. At the age of seven years, growth hormone deficiency was diagnosed. The MRI scan of the pituitary gland was normal, but many focal changes in brain tissue were found. The function of pituitary-dependent hormonal axes beyond GH/IGF1 axis was sufficient. Therapy with rhGH was introduced and continued for over nine years. Growth velocity increased and the height normalised appropriately to parental height. We did not observe any complications besides sporadic subcutaneous bleedings. Patients with haemophilia should be considered as a high-risk group for hypopituitarism. Subcutaneous rhGH injections can be safe even in severe haemophilia.
\end{abstract}

Key words:

haemophilia, GH deficiency, intracranial haemorrhage, children.

\section{Streszczenie}

Ciężka hemofilia jest związana z wysokim ryzykiem wystąpienia zagrażających życiu krwawień wewnątrzczaszkowych. Badania u dorosłych wskazują na stosunkowo wysoki odsetek niedoczynności przedniego płata przysadki po incydencie krwawienia wewnątrzczaszkowego. W pracy przedstawiono przypadek nabytej izolowanej somatotropinowej niedoczynności przysadki u chłopca z ciężką postacią hemofilii A. We wczesnym dzieciństwie przebył kilka incydentów krwawienia wewnątrzczaszkowego. W wieku 7 lat u chłopca rozpoznano niedobór hormonu wzrostu. Badanie metodą rezonansu magnetycznego wykazało prawidłową przysadkę i liczne zmiany ogniskowe w tkance mózgowej. Czynność osi hormonalnych zależnych od przysadki poza osią GH/IGF1 była prawidłowa. Wdrożono leczenie rhGH i kontynuowano terapię ponad 9 lat. Uzyskano normalizację wzrostu chłopca stosownie do średniej wysokości rodziców. Nie obserwowano żadnych powikłań leczenia poza sporadycznym krwawieniem po iniekcjach.

Pacjenci z hemofilią powinni być traktowani jako grupa zwiększonego ryzyka dysfunkcji przysadki. Podskórne iniekcje rhGH mogą być bezpieczne nawet u pacjentów z ciężką hemofilią.

Słowa kluczowe:

hemofilia, niedobór hormonu wzrostu, krwawienie wewnątrzczaszkowe, dzieci. 


\section{Introduction}

Severe haemophilia carries an increased risk of life-threatening intracranial haemorrhages $(\mathrm{ICH})$. The incidence of $\mathrm{ICH}$ in haemophilic children is estimated at $2.9-12 \%$ and is most common in young males, with a peak incidence from the age of 5.9 months to 2 years $[1,2]$. In the neonatal period the risk of $\mathrm{ICH}$ is estimated as $1-4 \%$, and this event is most likely within the first week of life [3].

In the general population the incidence of pituitary disorders after $\mathrm{ICH}$ due to traumatic brain injury (TBI) was thought to be low, and the most frequently mentioned transient posterior lobe dysfunction. Diabetes insipidus is estimated to be as frequent as $26 \%$ of patients in the acute phase of haemorrhage [4] and $6.9 \%$ among long-term survivors [5]. Nevertheless, studies in adult $\mathrm{ICH}$ survivors show a relatively high percentage of anterior pituitary hypofunction, ranging from $23 \%$ to $69 \%$ [6]. Isolated growth hormone deficiency (GHD) is reported as the most frequent $\mathrm{ICH} / \mathrm{TBI}$ complication. The onset of hypopituitarism is not closely related to the severity of trauma [7]. In most cases it occurs within the first year after TBI, but it might also arise several years after the incident [8-10]. In clinical studies following $\mathrm{TBI}$ the incidence of hypopituitarism varies from $15 \%$ to $68 \%$, and following subarachnoid haemorrhages (SAH) - from 37.5\% to $55 \%[6,8]$. In haemophilic patients hypopituitarism might be caused by either TBI or spontaneous $\mathrm{ICH}$. Therefore, children with inherited bleeding disorders should be considered as a group with increased risk of acquired hypopituitarism.

The aim of this paper is to present the case of GHD as a complication of severe haemophilia.

\section{Case study}

A boy was born from $6^{\text {th }}$ pregnancy by physiological $6^{\text {th }}$ delivery, birth weight $2850 \mathrm{~g}$ length $50 \mathrm{~cm}$, and Apgar score of 10. The patient's family history was positive for haemophilia: his two first cousins suffer from haemophilia $A$; therefore, the boy was investigated soon after birth, and severe haemophilia A was confirmed. In early childhood he underwent four spontaneous intracranial (subarachnoid and subdural) haemorrhages $(\mathrm{ICH})$ - the first in the $5^{\text {th }}$ month of life, the last at the age of three years. The diagnosis of $\mathrm{ICH}$ was based on the results of $\mathrm{CT}$, and the extent of the lesion in infancy was monitored using transfontanelle ultrasound.

At the age of three years the patient's height was in the $25^{\text {th }}$ percentile, concordant with parental height position, but for the next few years it steadily decreased. At the age of six years the patient's height was below the third percentile of male growth (Fig. 1). At this time the patient was diagnosed with chronic hepatitis type $\mathrm{B}$, but liver function was normal and biochemical liver markers were within referral ranges. At the age of seven years a hormonal investigation was performed. The bone age was retarded and was found to be at four years. The concentration of IGF-1 was significantly decreased: $21.5 \mathrm{ng} / \mathrm{ml}$ (88$265 \mathrm{ng} / \mathrm{ml})$. In two different stimulatory tests growth hormone
$(\mathrm{GH})$ secretion was below normal values (Table I). The function of other pituitary-dependent hormonal axes, i.e. thyroid and adrenal, was normal. Isolated GHD was diagnosed. In MRI scans the pituitary gland was normal, but multifocal changes of the brain tissue with the largest area of injury in posterior cranial fossa were found (Fig. 2). The therapy with recombinant human $\mathrm{GH}(\mathrm{rhGH})$ was administered. He started the treatment in the hospital under careful control of any injection. After several days the patient was discharged and continued the treatment at home. He was treated for over nine years with typical doses recommended for GHD children: $0.17-0.2 \mathrm{mg} / \mathrm{kg}$ body weight/ week. During the treatment the patient's growth velocity increased, and he achieved normal final height (Fig. 1). Additionally, during the rhGH treatment the body composition improved and lean body mass increased, which facilitated the physical activity of the patient. Under the treatment no complications were observed except sporadic small subcutaneous bleedings after injections. Puberty started at the age of 11 years and progressed normally. The hormonal function of the thyroid gland and adrenals remained within normal values.

\section{Discussion}

In haemophilic children the incidence of $\mathrm{ICH}$ is increased and can cause variable complications - neurological deficits, death, and hormonal deficiencies - as late complications. In the study by Kulkarini et al. the highest risk period of $\mathrm{ICH}$ was determined as the first month of life (1-4\% of neonates) and this event is most likely within the first week of life [3]. Hypopituitarism is defined as deficiency of one or more pituitary hormones of the anterior and/or posterior lobe, and it can be severe or partial. A prospective clinical study three months after $\mathrm{TBI}$ or SAH in adult patients in the intensive care unit revealed that severe and partial GHD were the most frequent pituitary defects after $\mathrm{TBI}$, at 25\%, and in SAH 25\% [11]. Moreover, the GHD is usually the first pituitary deficit to appear [8].

Data regarding the incidence of pituitary disorders after $\mathrm{ICH}$ in children is scarce $[12,13]$. The most common manifestation of $\mathrm{ICH}$-related pituitary dysfunction is $\mathrm{GH}$ deficiency [7]. In the data of worldwide pharmacoepidemiologic databases of children treated with growth hormone [14], hypothalamo-pituitary region injury after $\mathrm{SAH}$ was reported only in $0.6 \%$ of patients diagnosed with $\mathrm{GH}$ deficiency. Additionally, in patients with $\mathrm{GH}$ deficiency caused by traumatic brain injury only $38.2 \%$ had abnormalities of hypothalamic or pituitary structures detectable in MRI scans [14]. In our patient no demonstrable changes in $\mathrm{MRI}$ in hypothalamus or pituitary were found - only multifocal changes disseminated in the brain and a large empty area in the occipital part of the brain (Fig. 2). In the data collected by Kreitschmann-Andermahr [8] and Einaudi [12] isolated GH deficiency was diagnosed in 58.9\% of patients after brain injury, and the others had multiple deficiencies of other pituitary-dependent hormonal axes. In our patient the function of thyroid and adrenals was normal. Normal progress of puberty confirmed sufficient secretion of $\mathrm{GnRH}$ and gonadotrophins. 


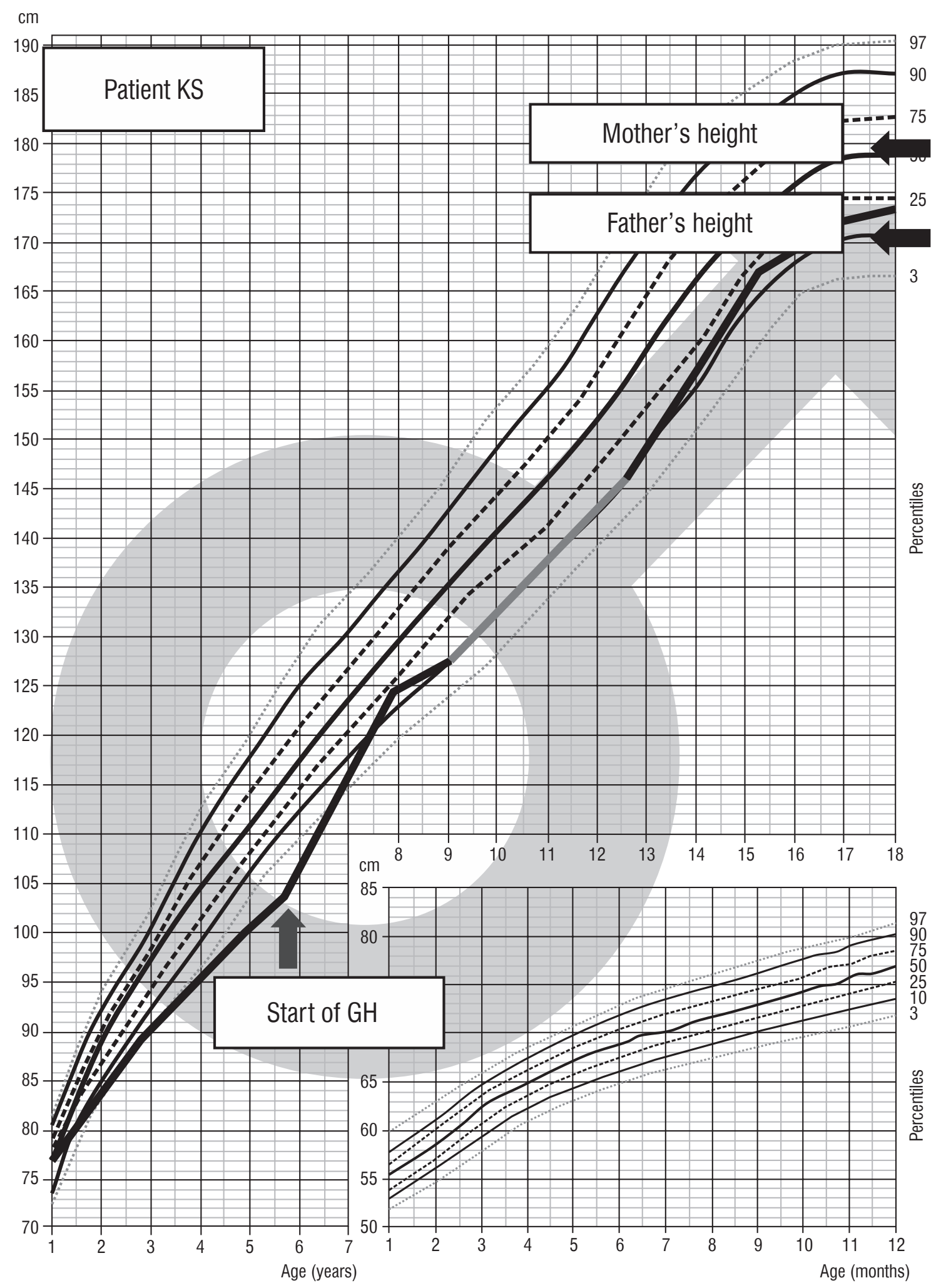

Figure 1. Growth chart analysis 
In adult GH deficiency is manifested by body composition changes, metabolic disturbances, and by psychiatric symptoms, such as depression [15]. In growing children, the most sensitive symptom that facilitates the diagnosis of GHD is decreased growth velocity. Additionally, a typical finding is retarded bone age and low serum insulin-like growth factor 1 (IGF1) and/

Table I. Results of stimulatory tests of GH secretion

\begin{tabular}{lll}
\hline $\begin{array}{l}\text { Duration of } \\
\text { blood sampling } \\
\text { (min) }\end{array}$ & $\begin{array}{l}\text { GH value after } \\
\text { clonidine } \\
(\mathrm{ng} / \mathrm{ml})\end{array}$ & $\begin{array}{l}\text { GH value after insulin } \\
\text { hypoglycaemia } \\
(\mathrm{ng} / \mathrm{ml})\end{array}$ \\
\hline 0 & 1.8 & 1.4 \\
\hline 15 & - & 0.5 \\
\hline 30 & 8.0 & 2.8 \\
\hline 45 & - & 4.5 \\
\hline 60 & 8.8 & 3.3 \\
\hline 90 & 3.9 & 6.2 \\
\hline 120 & 1.8 & 1.7 \\
\hline
\end{tabular}

Clonidine given orally at the dose of $150 \mu \mathrm{g} / \mathrm{m}^{2}$ body surface. Insulin given intravenously at the dose of $0.1 \mathrm{U} / \mathrm{kg}$ body weight. Normal value of $\mathrm{GH}$ secretion in children is estimated at over $10 \mathrm{ng} / \mathrm{ml}$. or insulin-like growth factor binding protein 3 (IGFBP3) $[16,17]$. In haemophiliac patients the evaluation of growth can be difficult because of articular deformations and mobility restrictions after frequent joint bleeds [18]. Therefore, short stature can be overlooked in those patients, even under thorough and careful medical control. In Poland a program of prophylactic factor VIII administration was introduced for patients with severe haemophilia A in 2008. Before that time, plasma-derived (pd) factor VIII was administered only as "treatment on demand" by bleeding. The presented patient was 16 years old when the prophylactic program was introduced and had previously had four intracranial bleeds, resulting in growth hormone deficiency. However, subcutaneous rhGH injections each day seemed risky due to possible haemorrhagic complications at the injection site, so we decided to start the treatment in a hospital environment. Despite the lack of prophylactic treatment there was no increase in bleeding into sites after subcutaneous rhGH administration. The therapy was continued safely in an outpatient setting. The course of therapy of our patient shows that the administration of subcutaneous rtGH preparations in haemophilic patients with $\mathrm{GH}$ deficiency does not require additional or increased doses of coagulation factor.

Because the incidence of hypopituitarism after $\mathrm{ICH}$ was found to be quite high, some authors recommend developing integrated screening programs for posttraumatic hypopituitarism as a standard of clinical care for patients with acute brain injury from trauma or $\mathrm{SAH}$. We propose to extend this recommendation to haemophiliac patients, especially those who have a history of brain trauma or intracranial haemorrhage events. It could be essential for the optimal care in haemophiliac patients and allows effective therapy.

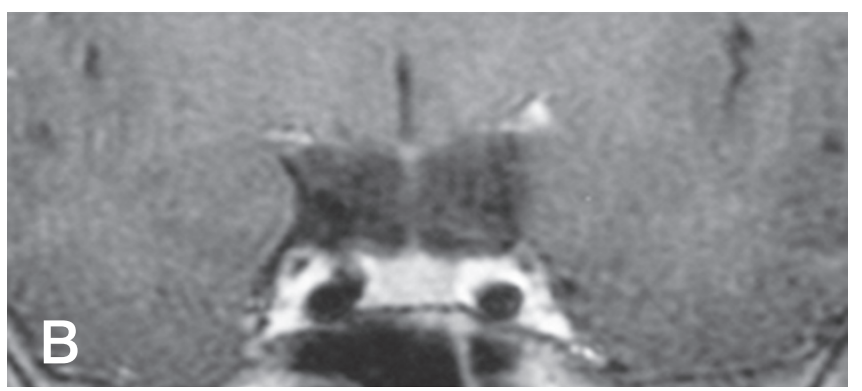

Figure 2. MRI scan of the CNS: A) multifocal post-haemorrhagic changes of the brain tissue with the largest area of injury in posterior cranial fossa; B) hypothalamo-pituitary region 


\section{Conclusions}

In children with haemophilia the growth should be systematically evaluated as a sensitive and simple marker of pituitary function (growth hormone, thyroid hormones).

\section{References}

1. Klinge J, Auberger K, Auerswald G, et al. Prevalence and outcome of intracranial haemorrhage in haemophilliacs - a survey of the paediatrics groupmof German Society of Thrombosis and Haemostasis (GTH). Eur J Pediatr 1999; 158 (suppl 3): S162-S165. doi: 10.1007/ pl00014346

2. Revel-Vilk S,Golomb MR, Achonu C, et al. Effect of intracranial bleeds on the health and quality of life of boys with haemophilia. J Pediatr 2004; 144: 490-495. doi: 10.1016/j.jpeds.2003.12.016

3. Kulkarini R, Lusher J. Perinatal management of newborns with haemophilia. Br J Hematol 2001;112: 264-274. doi: 10.1046/j.13652141.2001.02362.x

4. Agha A, Sherlock M, Phillips J, et al. The natural history of posttraumatic neurohypophysial dysfunction. Eur J Endocrinol 2005; 152: 371-377. doi: 10.1530/eje.1.01861

5. Glynn N, Agha A. The frequency and the diagnosis of pituitary dysfunction after traumatic brain injury. Pituitary 2019; 22: 249-260. doi: https://doi.org/10.1007/s11102-019-00938-y

6. Schneider HJ, Kreitschmann-Andermahr I, et al. Hypothalamopituitary Dysfunction Following Traumatic Brain Injury and Aneurysmal Subarachnoid Hemorrhage A Systematic Review. JAMA 2007; 298: 1429-1438. doi: 10.1001/jama.298.12.1429

7. Klose M, Juul A, Poulsgaard L, et al. Prevalence and predictive factors of post-traumatic hypopituitarism. Clin Endocrinol (Oxf) 2007; 67: 193-201. doi: 10.1111/j.1365-2265.2007.02860.x

8. Kreitschmann-Andermahr I, Hoff C, Saller B, et al. Prevalence of pituitary deficiency in patients after aneurysmal subarachnoid hemorrhage. J Clin Endocrinol Metab 2004; 89: 4986-4992. doi: 10.1210/ jc. 2004-0146

9. Can A, Gross BA, Smith TR, et al. Pituitary Dysfunction After Aneurysmal Subarachnoid Hemorrhage: A Systematic Review and Metaanalysis. Neurosurgery2016; 79:253-264. doi:10.1227/NEU.000000 0000001157
GH deficiency is a rare complication of haemophilia and can appear several years after intracranial haemorrhage.

The case of our patient shows that subcutaneous injections with rhGH can be effective and safe in patients with severe haemophilia.

10. Dimopoulou I, Kouyialis AT, Tzanella M, et al. High incidence of neuroendocrine dysfunction in longterm survivors of aneurysmal subarachnoid hemorrhage. Stroke 2004; 35: 2884-2889. doi: 10. 1161/01.STR.0000147716.45571.45.

11. Aimaretti G, Ambrosio MR, Di Somma C, et al. Hypopituitarism induced by traumatic brain injury in the transition phase. J Endocrinol Invest 2005; 28: 984. doi: 10.1007/BF03345336

12. Einaudi S, Matarazzo P, Peretta P, et al. Hypothalamo-hypophysial dysfunction after traumatic brain injury in children and adolescents: a preliminary retrospective and prospective study. J Pediatr Endocrinol Metab 2006; 19: 691-703. doi: 10.1515/jpem.2006.19.5.691

13. Fullerton HJ, Wu YW, Zaho S, Johnston SC Risk of stroke in children: Ethnic and gender disparities. Neurology 2003; 61: 189-194. doi: 10.1212/01.wnl.0000078894.79866.95

14. Mc Donald A, Lindell M, Dunger DB, Acerini CL Traumatic brain injury is a rarely reported cause of growth hormone deficiency. J Pediatr 2008; 152: 590-593. doi: 10.1016/j.jpeds.2007.12.046

15. Maric N, Pekic S, Doknic M. Depression following Traumatic Brain Injury Associated with Isolated Growth Hormone Deficiency: Two Case Reports. Horm Res 2007; 67: 177-179.

16. Wilson TA, Rose SR, Cohen P, et al. The Lawson Wilkins Pediatric Endocrinology Society Drug and Therapeutics Committee Update of guidelines for the use of growth hormone in children: the Lawson Wilkins Pediatric Endocrinology Society Drug and Therapeutics Committee. J Pediatr 2003; 143: 415-421. doi: 10.1067/s0022-3476(03)00246-4

17. Growth Hormone Research Society 2000 Consensus guidelines for the diagnosis and treatment of growth hormone $(\mathrm{GH})$ deficiency in childhood and adolescence: summary statement of the GH Research Society. GH Research Society. J Clin Endocrinol Metab 2000; 85: 3990-3993. doi: 10.1210/jcem.85.11.6984

18. Miles BS, Anderson P, Agostino A, et al. Effect of intracranial bleeds on the neurocognitive, academic, behavioural and adaptive functioning of boys with haemophilia. Haemophilia 2012; 18: 229-234. doi: 10.1111/j.1365-2516.2011.02632.x 